\title{
AIRCRAFT CORROSION - REVIEW OF CORROSION PROCESSES AND ITS EFFECTS IN SELECTED CASES
}

\author{
Magdalena Czaban \\ Institute of Aviation, Warsaw, Poland \\ Magdalena.czaban@ilot.edu.pl
}

\begin{abstract}
From the safety point of view, one of the most important issues regarding aircraft operations is ensuring the durability of the structural components. Corrosion processes can have a significant effect on the integrity of structural materials and are usually associated with aircraft aging. Due to the variety of materials used, environments and loads impacting the planes, a wide range of different types of corrosion may occur in aircraft structures. The main aim of this study is to present some theoretical knowledge related to corrosion processes as well as problems of aircraft structures associated with corrosion occurrence. Firstly, the paper presents a brief overview of what corrosion is and what different types of corrosion are. Secondly, some selected aircraft failures caused by corrosion are shortly presented and discussed.
\end{abstract}

Keywords: integrity of structure, corrosion processes, failures caused by corrosion

\section{INTRODUCTION}

Corrosion is an issue that has always accompanied metallic materials. Despite the materials selection and a lot of methods developed to provide proper protection, the problem of corrosion in metallic parts of aircraft remains unresolved. The dynamic growth of the aviation industry is related not only to demand for new aircraft but also to the need for the control and maintenance of plane parts of all the aircraft in a fleet. Such approach will enable them to operate as long and as safely as possible. The susceptibility to corrosion is determined by the time over which aircraft structures are used and by variable conditions to which they are exposed. 
In the literature a number of definitions of corrosion can be found. For the purposes of this analysis the author cites two of them.

Corrosion of metals - processes of gradual destruction (corrosion) of the metal structure as a result of its chemical reactions with environmental components or electrochemical processes. In many cases the direction of changes and their speed depends also on physical factors (e.g. stresses in elements of the loaded structure, external electric field, radiation) or microbiological [1].

According to the Universal Encyclopaedia, corrosion is: the process of destroying materials caused by external factors that may occur under the influence of chemical agents (e.g. oxygen, sulphur dioxide from the air), electrochemical agents (destructive effects of electrolyte solutions in contact with metals) and biological ones (the influence of some microorganisms) [2].

When describing corrosion processes, it is necessary to take into consideration that kinetic and thermodynamic processes condition them. While considering corrosion process from the perspective of chemical thermodynamics, it must be stated that metal corrosion is an inevitable spontaneous process. In the natural environment, only some metals commonly referred to as noble (platinum, gold) that are in an unconnected state are thermodynamically stable. Other metals, obtained as a result of the processing of their ores, often during very complicated metallurgical processes requiring large amounts of energy, are subjected to corrosion processes. Corrosion is a natural process in which metals return to the state of equilibrium of the thermodynamic system of metal-surroundings, previously disturbed by metallurgical processes. It is assumed that: among the changes that metals undergo when returning to a state of equilibrium with the environment, two basic groups are distinguished: electrochemical corrosion processes and chemical corrosion processes [3].

The citation above demonstrates the destructive nature of corrosion as causing material loss, called corrosion losses. Also, the definitions point out that the corrosion reactions is determined by the material and the environment.

In publication [4], researchers made an assessment based on their reports and data from incidents in history. That assessment showed that frequency of failures in aircraft components caused by corrosion, stress corrosion cracking (SCC), corrosion fatigue, hydrogen embrittlement and high temperature corrosion amounted to $25 \%$ [4]. Now, the problem of corrosion in airframes is very important because of its crucial economic implications [5]. The direct annual cost of corrosion in the aircraft industry of the USA is estimated to be $\$ 2.2$ billion in total. That price includes the cost of corrosion maintenance ( $\$ 1.7$ billion), downtime ( $\$ 0.3$ billion), and manufacturing ( $\$ 0.2$ billion) (estimated in 2002) [6]. 
While talking about the progression in researches and directions of future development of aircraft structures, the most important issue is how to ensure their best quality and reliability. Nowadays, materials predominantly used in producing airframe components are composites and metals. This review will concentrate on metallic structures and their susceptibility to corrosion processes with reference to different types of corrosion.

\section{DEFINITION OF THE MATERIALS AND TYPES OF CORROSION}

The metallic compounds that are in use in the airspace industry and discussed in this study are steel, aluminium and titanium alloys. In the year 2000, the content of steel in aircraft structures was estimated at $8.1 \%$ [7]. Nowadays, steel as a load-bearing element is being gradually replaced by aluminium and titanium alloys although it remains to be used in aircraft engines [7]. When corrosion is present in steel structures, it is easily recognised because the corrosion products form the red rust on the metal surfaces. If steel is not well protected, the steel elements will corrode in the presence of wetness. Low alloy steels (4000-8000 series) are susceptible to surface oxidation, pitting and intergranular corrosion attacks [8]. Aluminium alloys are the most important metallic materials used in the aerospace industry. The main additional components commonly used in aviation are: copper, silicon, manganese, magnesium and zinc [7]. The main components made from aluminium alloys are highly loaded elements such as girders, ribs, aircraft fabric covering, and cantilevers [7]. Connecting elements, such as rivets, may also be made from aluminium alloys. Corrosion on aluminium alloys reveals itself as gray to white powder [8]. Aluminium alloys are susceptible to a wide range of corrosion attacks including uniform surface corrosion, pitting, galvanic corrosion, intergranular and exfoliation corrosion attacks, stress corrosion cracking, crevice and fretting corrosion [8]. In the marine environment, if salts or industrial pollutants are present in the surroundings, all aluminium alloys require protection [8]. Titanium alloys are well-known for their great mechanical strength in relation to weight. They are characterised by very good chemical properties and excellent corrosion resistance [7]. There are no visible corrosion products on titanium alloys at low temperatures. However, coloured surface oxides can develop above $370{ }^{\circ} \mathrm{C}$ [8].

The corrosion phenomenon occurring on metallic structures is natural as metals tend to return to their natural state. Corrosion can mainly take place in the mechanisms of chemical or electrochemical action [9]. During these reactions, metals are converted into metallic compounds, such as oxides, sulphates and hydroxides [8]. Metallic compounds that are formed during corrosion processes 
typically have less strength than a pure metal or its alloy. In general, the corrosion that occurs in airframes is an electrochemical matter, caused by conductive solutions that assist metal ion transfer [10].

Two processes occur when a material is corroding. Firstly, there is dissolution of the metal which is an anode:

$$
\mathrm{Me} \rightarrow \mathrm{Me}^{2+}+2 \mathrm{e}
$$

This reaction must be balanced with cathodic reaction, for example, a reduction with dissolved oxygen:

$$
\mathrm{O}_{2}+2 \mathrm{H}_{2} \mathrm{O}+4 \mathrm{e} \rightarrow 4 \mathrm{OH}
$$

Or a reduction of hydrogen ions to hydrogen gas:

$$
2 \mathbf{H}^{+}+\mathbf{2 e} \rightarrow \mathbf{H}_{2}
$$

The conditions that are critical for corrosion to occur are as follows: the presence of two dissimilar metals which, because of their different potentials, will act as an anode and cathode, the occurrence of electrolyte (conductive liquid) and an electrical contact between the anode and the cathode [11]. Under uncoupled corrosion, the anodic and cathodic reactions occur in the local areas of the material [12]. The limitation of occurrence of one of the above factors results in the limitation of the whole corrosion process [11].

\section{Environment}

Although the aerospace industry is continuously developing better and better materials, this progress can be partly offset by aggressive environment [8]. The development of corrosion processes on different types of aircraft will occur in various ways. Atmospheric corrosion is the consequence of the interaction between a metal and its environment. But the problem with corrosion occurring on flying aircraft structures is a complex phenomenon with many parameters impacting its nature, varying with the geographical location, aircraft range, local climate and changes in weather. Also, aircraft in service remain on the ground in their bases most of the time and the environment in their military unit will be an important factor while considering corrosive processes likely to occur.

Since the presence of various types of contamination in the atmosphere can cause acceleration of corrosion, atmospheres were divided based on their purity in order to assess their corrosivity. According to this division, we can distinguish the following atmospheres: rural, urban, industrial and marine. Marine environments are dangerous as they contain electrolytes such as chlorides in the form of salt solutions [8]. Most salts are likely to promote 
corrosive processes as they are good electrolytes and can be harmful to aircraft structures made of aluminium alloys or not stainless steel alloys [8]. The marine environment corrosiveness depends on factors such as topography of the shore, wave action, relative humidity and winds [13]. The main corrodant in the marine air is sodium chloride, dispersed either as dry particles or liquid aerosol [13]. Chlorides are natural components of air, especially in the coastal areas but their concentration decreases with the distance from the coastline [14]. Chlorides and possible corrosion products that are situated on a surface can be easily rinsed by rainfall, so covered surfaces pose a greater threat [14]. Indicative of corrosion processes occurring in the presence of chloride ions are among others corrosion pits, crevices or other morphological changes of local character [14].

What is more, during its missions an aircraft can be temporarily exposed to external factors such as dust, dirt, impact of objects that may violate the top layers of the material or damage the paint coat, and exposure to factors appearing during maintenance may leading to an increase in corrosivity if performed unprofessionally. An example of this type of corrosion is shown in [15]. Graphite-containing grease was used by contractors on the F16 USAF single-engine fighter aircraft despite the Air Force prohibiting its use in aircraft due to its well-known effect of galvanically induced corrosion in bimetallic couples [15]. This maintenance action led to the occurrence of corrosion between the electrical connectors made of combined tin and gold plated steel pins, which were controlling the fuel line shutoff valve [15]. The corrosion that occurred between those metals led to a loss of control of the valve. It is believed that at least seven aircraft have been lost by valves shutting off the fuel in midflight [15].

Different types of corrosion can be distinguished by defining the range and morphology of corrosion. These different types of corrosion may vary depending on the chemical composition of a part, corrosive media in the part's location and the time and length of exposure to corrosive factors. In the description below, a brief review of different types of corrosion is presented. This list will not include all types of corrosion in general, because there are also other types that can occur under given conditions. However these types can be found on aircraft structures.

\section{Pitting corrosion}

Pitting corrosion manifests itself in the form of holes in the structure. Although it can be caused by a number of factors, in most cases it is formed in the presence of chloride ions $\left(\mathrm{Cl}^{-}\right)$in electrolyte environment in direct contact with the material. Corrosion pits may differ in shapes but they usually develop and 
grow vertically and deep into the material. Pits may also initiate the mechanism of formation of extensive fatigue cracks resulting in material strength decrease [16]. The influence of pitting on the fatigue of a structure is currently not fullyknown [16]. Many research studies have focused on analysing the possible influence of pitting corrosion on fatigue cracks propagation in aluminium alloys $[16,17,18]$.

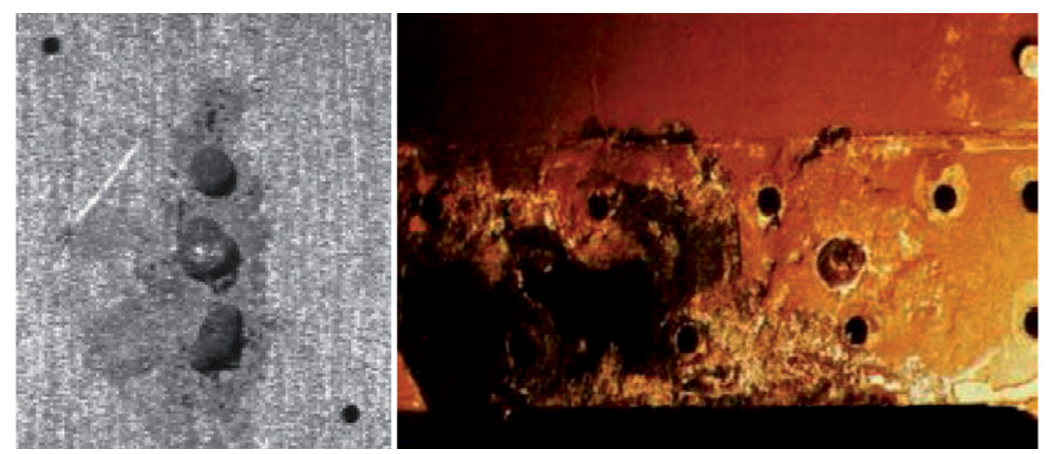

Fig. 1. Corrosion pits on the surface [19]

\section{Crevice corrosion}

Crevice corrosion is usually localized in crevices or gaps in the surface or places where local stagnation of condensates may occur and the circulation of electrolytes is hindered. The presence of electrolytes in the space between two parts makes it possible to connect them by conductivity [20]. Crevice corrosion can be very destructive and can occur in materials that by definition have very good corrosion resistance, and in hidden places. Crevice corrosion may lead to sudden damage. The discontinuities of the structure where crevice corrosion is usually located are typically geometric elements whose shape results from the structure. These can be, for example: rivets, welds, joints; contact places between a metal and a non-metal, such as composites, glass, rubber; impurities or unremoved corrosion products forming sediments on the surface.

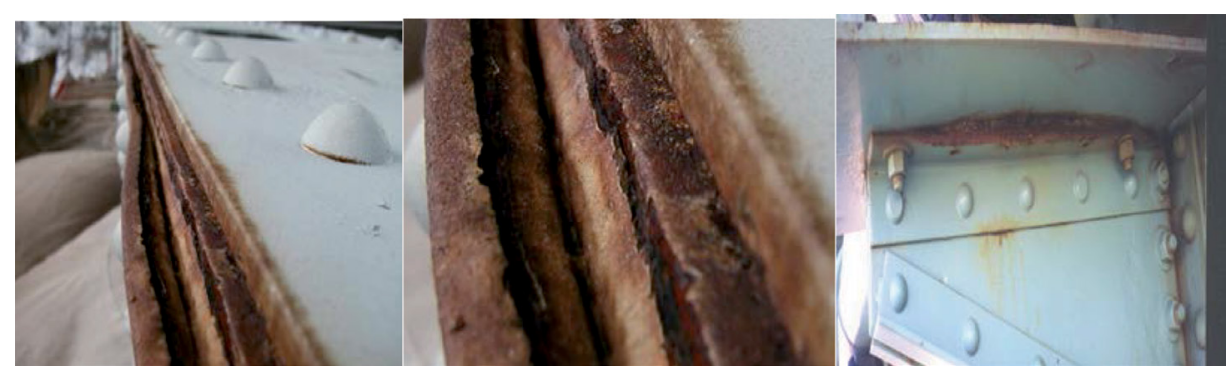

Fig. 2. Crevice corrosion on steel elements [21] 
Galvanic corrosion (bimetallic corrosion)

Galvanic corrosion occurs when there is a connection of two dissimilar metals in the system. Metals with a lower potential will act as an anode (giving its ions to the system) while metals with higher electrochemical potential will be cathodes.

An example of corrosion caused by a difference in electrochemical potential between the elements of a system is shown in (Fig. 3).

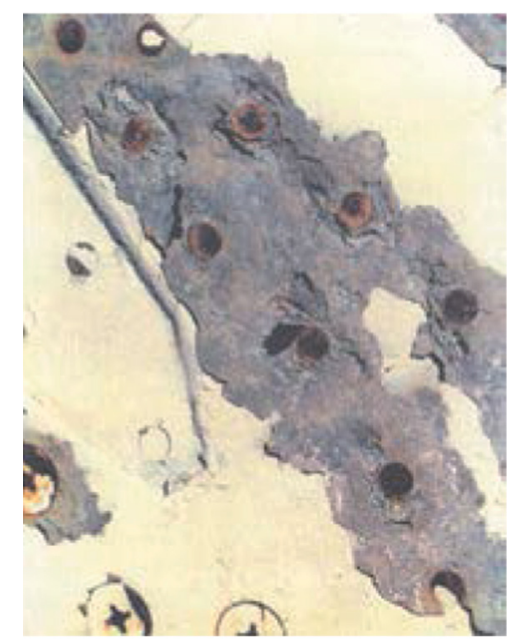

Fig. 3. Galvanic corrosion between magnesium surface and steel connections [22]

\section{Intergranular corrosion}

Intergranular corrosion occurs along the grain of the material when stresses are applied perpendicularly to the grain boundaries. High-strength aluminium alloys are susceptible to this type of corrosion if heat treatment was provided incorrectly and if they are exposed to corrosive environments.

\section{Exfoliation corrosion}

Exfoliation corrosion occurs along the longitudinal grain boundaries in the direction of rolling. When it occurs, exfoliation corrosion may cause a separation of grains in the metal grain layers. It has a layered character. It can be formed in unharmed grain ends, e.g. fixing holes and board edges (Fig. 4). 


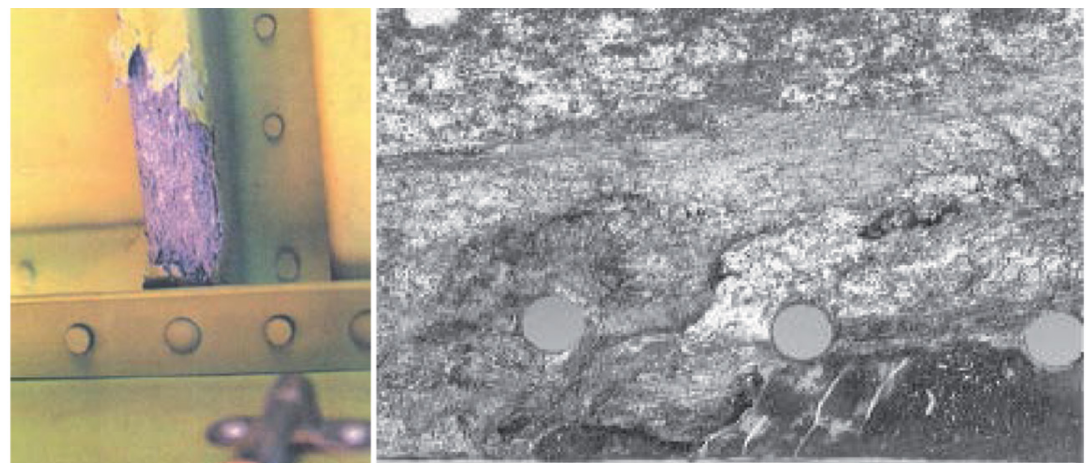

Fig. 4. Exfoliation corrosion [22] [23]

Types of corrosion that may occur when the corrosion processes are not detected fast enough:

\section{Stress corrosion cracking (SCC)}

The crack growth mechanism involves simultaneous interaction of the static tensile stress, corrosive environment and metallurgical factors, primarily the chemical composition and the alloy structure. SCC often develops from the pitting or crevice corrosion. Stress levels at which this type of cracking occurs are characterized by significantly lower values than those causing the cracking of parts made of the same type of material.

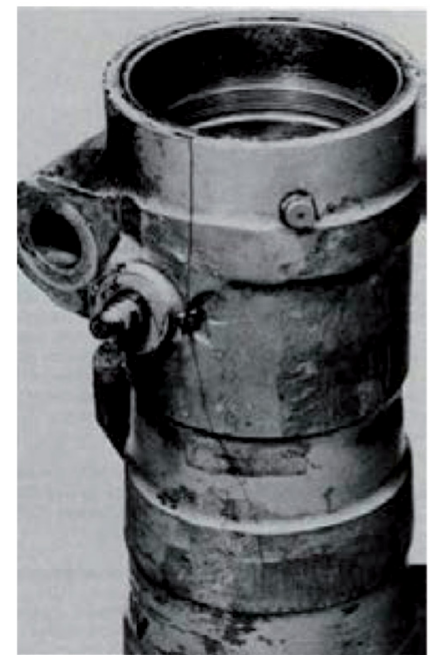

Fig. 5. Crack resulting from undetected stress corrosion [19] 


\section{Hidden corrosion}

Hidden corrosion is a type of degradation of the material which is not detectable visually or by surface techniques. The occurrence of hidden corrosion can be identified and measured in terms of thickness reduction or the occurrence of structural discontinuities such as pitting, structural defects or a loss of material. Hidden corrosion is associated with the "pillowing" corrosion effect. It occurs when the adjacent layers of the material are torn apart as the corrosion process in a closed space increases. Chemical analyses carried out on products indicate the presence of metal oxides accumulated in a closed space between materials. In addition, the molecular volume of aluminium oxide is greater than that of pure aluminium, which, with the increase in the time of the corrosion process, results in the formation of local surface deformations.

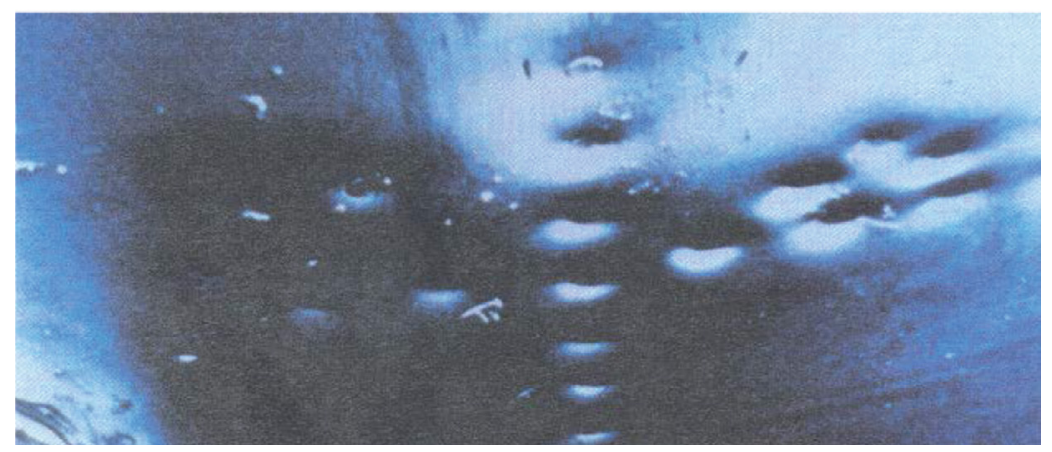

Fig. 6. Hidden corrosion [22]

\section{EXAMPLES OF CORROSION IN AIRCRAFT ACCIDENTS}

Proper and comprehensive attention paid to the control of corrosion intensity in aircraft structures can have a significant effect on the airworthiness of aircraft. But firstly, it is important to understand the distinction between an aircraft accident and incident. An aircraft accident, according to [24], is an event associated with the operation of an airplane that starts when the first person entered it with intention to fly and finishes when all the people on board have left the aircraft, and during which:

1. Any person has been fatally or seriously injured as a result of: being on the board of an aircraft or; in direct contact with any part of the aircraft, including the part which has separated from the aircraft or; directly exposed to a gas or air steam from the aircraft, with the exception of those cases when the injury was a result of natural or self-inflicted causes or by another person, or when the injured people were flying without permission or hiding in places which are usually locked up for access for passengers and crew members; 
2. The aircraft has been damaged or its structure has been damaged and as a result: the durability of the structure has been compromised and technical deterioration or flight characteristic losses have occurred or; a major overhaul or replacement of the defective component is required.

3. The aircraft has disappeared or is at the point where access to it is not possible [24].

An aircraft incident is an occurrence, other than an air accident, related to the operation of an aircraft that has or could have an impact on it safety [24].

In the following section, the cases of aircraft failures that indicate an undisputed negative impact of the changes in the material integrity and strength caused by corrosion are presented.

$\rightarrow$ Crash of MiG 23 aircraft in the Kortijk cottage (1989):

The failure of the engine control system was the main reason of a catastrophic crash of MiG 23 Flogger from the base in Bagicz (near Kołobrzeg in Poland) in year 1989. During this flight, the aircraft had covered about $900 \mathrm{~km}$ without the pilot inside [25]. The pilot had been ejected earlier because of a loss of engine power after turning on the afterburner, during a climb-out, which he considered to be the engine shutdown. After the pilot's ejection, the plane flew at a speed of around $400 \mathrm{~km} / \mathrm{h}$ and disappeared by the sea. Pilots of two other fighters were sent to a reconnaissance and they confirmed a probable plane crush (into the Baltic Sea) [26]. Indeed, shortly after the pilot left the cabin, the engine regained power and due to the stabilisation system which controlled the flight parameters, it was flying until no fuel was available. The flight ended with a final catastrophic collision with a house after a slow fall to the ground and in one fatal injury [25], [27].

The blame for the catastrophic accident was in part placed on the repair companies [25], [28]. The unstable engine performance was caused by electrochemical corrosion in the engine control system, which should have been detected during the inspection. The considered cause of corrosion was the influence of sea water [28] as the airplanes had been performing their flights offshore the Baltic Sea in the marine environment. These MiG 23M planes first flew in 1972 [29]. Soviet MiG 23M planes were allocated in the Bagicz regiment in 1973 [25]. The service life defined by the manufacturer was 17 years [30]. After that incident, MiG 23M planes were relocated. This case shows that corrosion may occur in hidden places or elements and a usual maintenance inspection without a proper examination of possible 
corrosion may not prevent from failures resulting in disasters. Moreover, the corrosion occurred on the metallic structure before the service life assigned by the manufacturer reached its end, which could have been caused by an environment accelerating corrosion.

$\rightarrow$ Aloha Airlines flight Boeing 737, 04.28 .1988 (Hawaii)

After levelling off the flight of Boeing 737 to $24000 \mathrm{ft}$. (8000m) cruising altitude, the pilots in the cabin heard a whooshing sound from the fuselage followed by a windy noise. The capitan of the plane observed that "there was blue sky where the first class ceiling had been" [31]. In fact a large segment of the upper part of the fuselage was torn off from the plane which created a large hole in the passenger cabin [32]. A major part of the upper crown skin of section 43 was separated during the flight. This caused an explosive decompression in the cabin. The pilot immediately took control of the plane [31]. The first officer reported the emergency to the air traffic controller in Honolulu and informed the Maui airport traffic control about an emergency landing [31]. The pilot managed to land on the island of Maui [15]. This catastrophic accident resulted in the death of one person - a flight attendant who stood in the passing during the separation of the segment from the fuselage [15]. The investigation of the remaining aircraft structure showed multiple fatigue cracks in the holes of the upper row of rivets in several fuselage skin lap joints [15]. Because the overlapping panels were provided to remain strongly bonded, the fatigue cracks were not predicted to be a problem likely to cause a structural damage to the aircraft. The inspection in the lap joints of other airplanes showed that the problem was connected with disbonding, corrosion and cracking problems [15]. The "pillowing" phenomenon caused by build-ups of voluminous corrosion products inside the lap joints led to a separation of the faying surfaces [15].
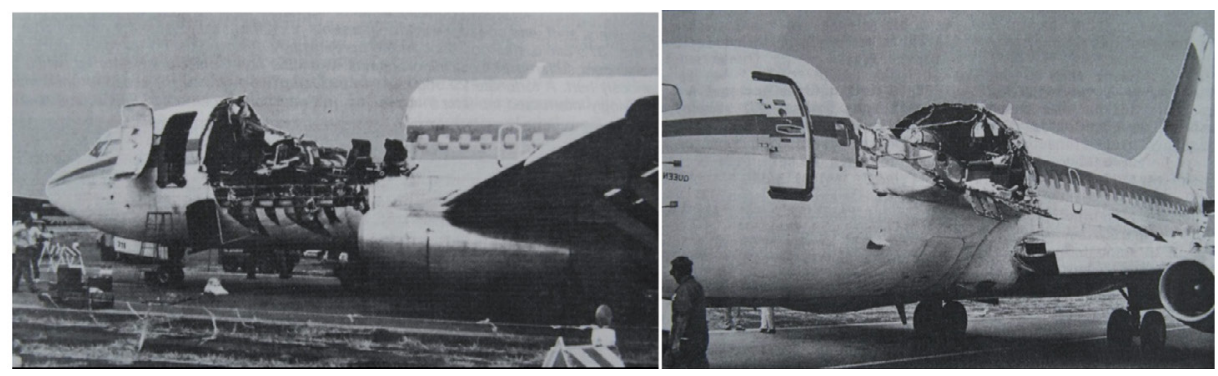

Fig. 7. Boeing 737 from Aloha Airlines after the accident [33] 
The airplane was a 19-year-old Boeing 737 [15], manufactured in 1969 and delivered to the Aloha Airlines in the same year. The Aloha Airlines had eleven Boeings 737, all with flight cycles of 60000 or more [31]. This specific jet had accumulated 35496 flight hours and 89680 flight cycles [31]. The airlines were not aware of the effect of the flight cycle accumulation [31]. In fact, the maintenance record showed that corrosion was detected by personnel providing the maintenance but there were no corrective actions undertaken that should have followed that discovery. The team accepted the signs of the ongoing corrosion as a normal operating condition [34], [31]. At that time, the corrosion prevention and control programs (CPCP) were not available for an entire plane. The Aloha Airline accident was the initiator of the recommendations to develop a model for CPCP that would be a part of every operator's maintenance programs [34]. It is visible how important the plane use rate is. An intensified exploration under demanding conditions in a wide range can decide about the occurrence of possible corrosion failures. This aspect should be taken into account when carrying out research aimed at prolonging the service life.

$\rightarrow$ Incident of Zenair CH-601HD (05.07.2016)

The incident happened while performing the check flight after the engine repair [35]. During the run-up just before the takeoff, at the speed of approx. $80 \mathrm{~km} / \mathrm{h}$, the wheel from the right landing gear separated from the plane [35]. The separation of the lower tile from the gear took place around the joint connecting these parts [35]. The tile was destroyed (Fig. 8).

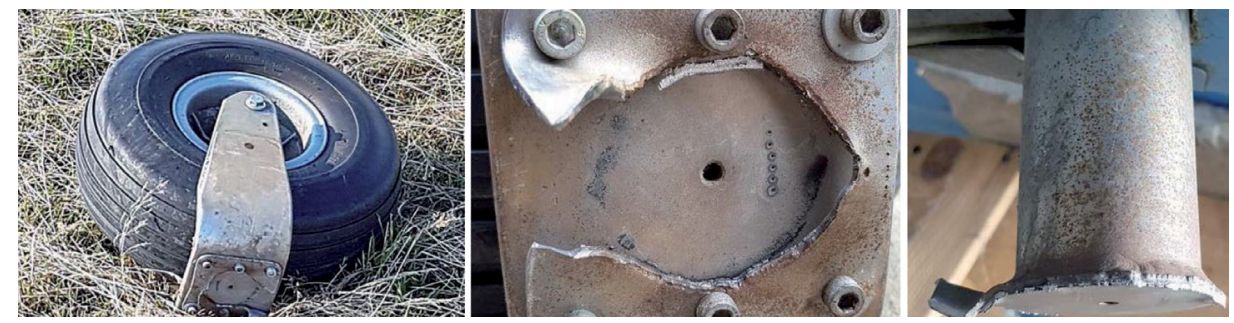

Fig. 8. The separation of wheel from the landing gear [35]

From the photographic documentation, it can be seen that a significant part of the weld (over $25 \%$ of its length) showed signs of corrosion penetration, which had significantly reduced the strength of the joint and initiated the process of its destruction [35]. Moreover, the authors of the report [35] admitted that the corrosion penetration into the weld could not have been detected during the standard visual inspection as its detection would have required disassembling 
parts and the use of an appropriate defectroscopy method. The official cause of the accident was the destruction of the connection between the landing gear and the tile caused by corrosion penetrating the weld resulting from long-term operation time [35]. This incident shows how important it is to select proper detection techniques, adequate to the structure and the information that we want to gather.

Despite the fact that corrosion prevention involves a significant financial burden, it is important not to underestimate the corrosion problem as it can lead to catastrophic damage to aircraft.

\section{CONCLUSIONS}

This paper presented a brief review of the corrosion phenomena occurring in aircraft. The conclusions drawn from the literature studies are as follows:

- Due to a significant increase in the importance of air transport, the problem of ensuring the reliability of aircraft structures is extremely important. Despite the increasing use of composite materials, some parts and components of aerospace structures are still made of metals, which cannot be fully eliminated. This makes it necessary to carry out studies and research the fields focused on maintaining the integrity of metallic structures.

- Corrosion occurs in structures made of metals and metal alloys. Corrosion processes progress over time. Not detected and defined early enough and not properly repaired, corrosion changes can lead to disintegration of aircraft and loss of structural strength.

- The environment of the base where the aircraft is stationed is important. The aircraft will remain on the ground for the majority of its useful life despite being operated in the air and regardless of the intensity with which it carries out the activities entrusted to it. The environmental conditions influencing the aircraft in different units and bases may vary depending on the geographical location.

- Corrosion in structural parts of an aircraft can take many forms. The strength of a metallic structure can be changed by corrosion and its decrease may vary depending on the type of corrosion.

- Corrosion prevention and control programmes provide basic information for managing corrosive processes taking place on aircraft structures.

- Aircraft corrosion is the problem that affects many military and civil aircraft.

- Corrosive damage can cause crack propagation and stress accumulation, and the progressive corrosion processes can result in a significant decrease in the mechanical characteristics of the airframe material. The final effect 
of an untreated ongoing corrosion process can be corrosive destruction causing the aircraft system to fail.

- Although corrosion is a phenomenon affecting almost all ageing aircraft, there is no one simple and fixed method to counteract it. The approach recommended by this study involves complex actions including prevention, monitoring, maintenance carried out with adequate techniques and the personnel understanding the corrosion processes, coupled with proper rework or replacement of the corroded parts, it is the best way to counteract corrosion processes.

- Research and development aimed at determining the degree of aircraft exploitation, and taking into account the onset of corrosion processes, is a very important element in determining the possible impact of damage caused by corrosion of aircraft structures.

\section{REFERENCES}

[1] Encyklopedia techniki. Chemia, Warszawa, Wydawnictwo Naukowo-Techniczne, 1993, pp. 361-365, 488.

[2] Encyklopedia Powszechna, Poznań, Wydawnictwo IBIS, 2011, p. 381.

[3] G. Kortum, Elektrochemia, Warszawa: Państwowe Wydawnictwo Naukowe, 1970.

[4] S. Findlay and N. Harrison, Why aircraft fail, Materials Today, pp. 18-26, November, 2002.

[5] R. Kinzie, Cost of Corrosion Maintenance, in 2 nd Joint NASA/FAA/DoD Conference on Aging Aircraft, Williamsburg, VA -USA, 1998.

[6] P. Virmani, Corrosion costs and preventive strategies in The United States, PUBLICATION NO. FHWA-RD-01-156, March 2002. [Online]. Available: https:// pdfs.semanticscholar.org/d2c2/12bcec8dc5ef6d31a00d6a0202f8e7fbb2e9.pdf. [Accessed 3011 2018].

[7] R. Bielawski, R. Witold, S. Augustyn and P. Pyrzanowski, Nowoczesne materiaty stosowane w konstrukcjach lotniczych - wybrane problemy oraz kierunki rozwoju, Zeszyty naukowe Politechniki Rzeszowskiej, Mechanika 87, vol. XXXII, no. 87 (3/15), pp. 203-216, 2015.

[8] U.S. Departament of Transportation FAA, Advisory Circular: Corrosion Control for Aircraft, 2018.

[9] S. Butnicki, J. Ćwiek, A. Degórski, M. Głowacka, J. Hucinska, T. Jankowski, Z. Królikowski, T. Krzysztofowicz, J. Łabanowski, S. Rymkiewicz, W. Serbiński, J. Stryjewski and Z. Zaczek, Metaloznawstwo, Gdańsk: Wydawnictwo Politechniki Gdańskiej, 1996. 
[10] M. Colavita, Occurrence of Corrosion in Airframes, in Aging Aircraft Fleeds: Structural and Other Subsystem Aspects, Sofia, Bułgaria, 2000.

[11] Federal Aviation Administration, Corrosion control for aircraft, Waschington, DC: Advisory Circular, 1991.

[12] National Physical Laboratory, Bimetallic Corrosion, in Guides to Good Practice in Corrosion Control, Crown Copyright, 2000, pp. 1-15.

[13] R. Vashi and H. Kadiya, Corrosion study of metals in marine enviroment, E-Journal of Chemistry, pp. 1240-1246, 2009.

[14] J. Kobus and L. Kwiatkowski, Monitoring of atmospheric corrosion agents and their effects on corrosion rate, Inżynieria Powierzchni, pp. 3-16, 2009.

[15] P. Roberge, Handbook of Corrosion Engineering, New York: McGraw-Hill, 2000.

[16] S. J. Rokhlin, J. Kim, H. Nagy and B. Zoofan, Effect of pitting corrosion on fatigue crack initiation and fatigue life, Engineering Fracture Mechanics, pp. 425-444, 1999.

[17] G. S. Chen, M. Gao, D. Harlow and R. Wei, Corrosion an Corrosion fatigue of airframe aluminum alloys, Bethlehem, USA: Lehigh University.

[18] D. DuQuensay, P. Underhill and H. Britt, Fatigue crack growth from corrosion damage in 7075-T6511 aluminum alloys under aircraft loading, International Journal of Fatigue, pp. 371-377, 2003.

[19] W. Wallace, D. Hoeppner and P. Kandachar, AGARD Corrosion Handbook Volume 1. Aircraft Corrosion: Causes and Case History, NATO, 1985.

[20] I. Siggelkow, Evaluation of corrosion in crevices, Uppsala: Uppsala Universitet, 2012.

[21] W. Senick, C. Ballinger and R. Mondor, CorrosionIsms: Unravelling the Mysteries of Steel Corrosion, in SEBPP Partnership Conference, Montgomery, 2015.

[22] Federal Aviation Administration, VISUAL INSPECTION FOR AIRCRAFT, U.S. Department of Transportation: Advisory Circular, 1997.

[23] K. Sharp, G. Clark and Q. Liu, Effects of Exfoliation Corrosion on the Fatigue Life of Two High-Strength, in DoD/FAA/NASA 2000 Ageing Aircraft Conference, St Louis, Missouri, 2000.

[24] Ustawa z dnia 3 lipca 2002 r.- Prawo lotnicze (Dz. U z 2012 r, poz 933,951,1544. z 2013 r. poz 134, 628, 829,912).

[25] Muzem Zimnej Wojny, [Online]. Available: http://zimnawojna.info/podborsko/15region/17-historia-lotniska-w-bagiczu. [Accessed 2611 2018].

[26] "https://gk24.pl/ucieczka-i-skandal-czyli-mig23-leci-z-podkolobrzeskiegobagicza-na-zachod/ar/10536819/2," [Online]. Available: https://gk24.pl/ ucieczka-i-skandal-czyli-mig23-leci-z-podkolobrzeskiego-bagicza-na-zachod/ ar/10536819/2. [Accessed 2611 2018]. 
[27] M. Gaines, Runway MiG crashes in Belgium, Flight International, p. 6, 15 July 1989.

[28] "http://strefahistorii.pl/article/1963-bezzalogowy-mig-z-kolobrzegu-nad-belgia," [Online]. Available: http://strefahistorii.pl/article/1963-bezzalogowy-mig-zkolobrzegu-nad-belgia. [Accessed 2611 2018].

[29] Samoloty w Lotnictwie Polskim, [Online]. Available: http://www.samolotypolskie. pl/samoloty/1860/126/Mikojan-MiG-23. [Accessed 2611 2018].

[30] "http://samolotypolskie.blogspot.com/2014/08/mig-23-pechowy-mysliwiec. html," [Online]. Available: http://samolotypolskie.blogspot.com/2014/08/mig-23pechowy-mysliwiec.html. [Accessed 2611 2018].

[31] N. Hashmi, Revisiting Aloha Airline Flight 243: Corrosion Engineer's stad point, [Online]. Available: https://faculty.up.edu/lulay/me401/aloha_flight_243_a_new_ direction.pdf. [Accessed 3011 2011].

[32] Z. Petrovic, Catastrophes caused by corrosion, Military Technical Courier, pp. 1048-1064, 2016.

[33] “Aviation Safety Network," 1008 2018. [Online]. Available: https://aviationsafety.net/database/record.php?id=19880428-0. [Accessed 1910 2018].

[34] C. Giles, M. Halliburton, S. Keller and F. Leonelli, REQUIREMENT FOR CORROSION PREVENTION AND CONTROL PROGRAM STUDY, U.S. Department of Transportation Federal Aviation Administration, New Jersey, 2016.

[35] T. Makowski, Informacja o zdarzeniu nr. 1590/16, Państowowa Komisja Badania Wypadków Lotniczych, 2016 